\title{
Tropical Peat as a Versatile Material for Solid-Phase Extraction of Pesticides from Medicinal Plant Cordia salicifolia
}

\author{
Pedro H. V. de Carvalho, Amanda M. D. de Jesus, Vanessa M. Prata, \\ Débora S. S. Bezerra, Luciane P. C. Romão and Sandro Navickiene* \\ Departamento de Química, Universidade Federal de Sergipe, Av. Marechal Rondon s/n, \\ 49100-000 São Cristóvão-SE, Brazil
}

\begin{abstract}
A turfa natural foi testada na extração em fase sólida de acefato, clorprofam, pirimicarbe, bifentrina, tetradifona e fosalona da planta medicinal Cordia salicifolia, utilizando cromatografia a gás acoplada a espectrometria de massas no modo de monitoramento de íons selecionados. Considerando que a legislação brasileira não estabelece limites máximos de resíduos para plantas medicinais, a recuperação foi avaliada em dois níveis de concentração $\left(0,5\right.$ e $\left.1,0 \mathrm{mg} \mathrm{kg}^{-1}\right)$, resultando em valores de recuperação entre $64 \%$ e $118 \%$, com coeficientes de variação entre $5,6 \%$ e $26,4 \%$ para a turfa. Os limites de detecção variaram entre 0,10 e $0,15 \mathrm{mg} \mathrm{kg}^{-1}$, enquanto que os limites de quantificação, entre 0,15 e $0,25 \mathrm{mg} \mathrm{kg}^{-1}$ para os pesticidas estudados. O método desenvolvido foi linear no intervalo de 0,1 a $5,0 \mu \mathrm{g} \mathrm{g}^{-1}$, com coeficientes de correlação entre 0,9975 e 0,9986 . A comparação entre a turfa natural e o sorbente convencional (alumina neutra) apresentou desempenho similar da turfa na recuperação dos seis pesticidas.
\end{abstract}

Natural peat was tested for solid-phase extraction of acephate, chlorpropham, pirimicarb, bifenthrin, tetradifon and phosalone from the medicinal plant Cordia salicifolia, using gas chromatography-mass spectrometry with selected ion monitoring (GC/MS, SIM). Considering that there are no Brazilian regulations concerning maximum permissible pesticide residue concentrations in medicinal herbs, recovery experiments were carried out (three replicates) at two arbitrary fortification levels $\left(0.5\right.$ and $\left.1.0 \mathrm{mg} \mathrm{kg}^{-1}\right)$, resulting in recoveries ranging from $64 \%$ to $118 \%$ and relative standard deviations between $5.6 \%$ and $26.4 \%$ for peat sorbent. Detection and quantification limits for herb ranged from 0.10 to $0.15 \mathrm{mg} \mathrm{kg}^{-1}$ and from 0.15 to $0.25 \mathrm{mg} \mathrm{kg}^{-1}$, respectively, for the different pesticides studied. The developed method was linear over the range assayed, 0.1-5.0 $\mu \mathrm{g} \mathrm{g}^{-1}$, with correlation coefficients ranging from 0.9975 to 0.9986 for all pesticides. Comparison between natural peat and conventional sorbent (neutral alumina) showed similar performance of peat for the six pesticides tested.

Keywords: peat, pesticides, medicinal herb, matrix solid phase dispersion, gas chromatographymass spectrometry

\section{Introduction}

Medicinal plants are consumed worldwide for treatment of disease and are important raw material for pharmaceutical industry production for phytopharmaceuticals. The significant increase in the use of medicinal herbs in recent decades may be attributed to popular knowledge, the cost of synthetic drugs and the resurgence of interest in the development of new drugs. World Health Organization report indicated that about $70-80 \%$ of the world population rely on non-conventional medicines mainly of herbal

*e-mail: sandnavi@ufs.br sources in their primary health care. ${ }^{1}$ Traditionally herbs and herbal products have been considered to be gentle, nontoxic and even harmless mainly because of their "natural" origin..$^{1-3}$ Cordia salicifolia Cham (Boraginaceae family syn. Cordia ecalyculata Vell.) also known by several common names such as "porangaba", "chá do bugre" or "café do mato" is a small tree producing as its peculiar feature fruits resembling a coffee beans. Extracts of this plant are commercialized in Brazil as diuretic, appetite suppressant and weight loss products. However, like other crops, medicinal plants also are susceptible to insect and disease attacks both in field and storage, so pesticides are widely used for their protection. ${ }^{2,4}$ Besides, different products, 
like acephate, chlorpropham, pirimicarb, bifenthrin, tetradifon and phosalone, are used to control phytophagous insects and fungal pathogens on a variety of crops in the Northeastern part of the Brazil. When applied, they can be transferred to the medicinal herb Cordia salicifolia plantation. In general, most methodologies for pesticide analysis in medicinal plants and their products, such as the EP (European Pharmacopoeia) procedure, are costly, time-consuming and require larger samples and greater volumes of hazardous solvents. ${ }^{5}$ To overcome some of the disadvantages, analytical techniques such as MSPD (matrix solid-phase dispersion) have been successfully employed. ${ }^{6}$ It avoids the drawbacks generally associated with liquidliquid extraction, such as the use of large volumes of solvent, the occurrence of troublesome emulsions and slow speed. ${ }^{7}$ The principle of this technique is based on the use of the same bonded-phase solid supports as in solidphase extraction (SPE), which also is used as grinding material for producing the disruption of sample matrix. During this procedure, the bonded-phase support acts as an abrasive, and the sample disperses over the surface of the support. The MSPD technique has many applications to the processing of samples of biological origin (animal tissues, plant materials, fats etc). ${ }^{8-16}$ The literature describes chromatographic methods for the determination of pesticide residues in medicinal plants using classical sorbent material such as $\mathrm{C}_{18}$-bonded silica. ${ }^{17-24}$

During recent years, research on new materials for extraction, purification and separation processes of organic compounds in a wide polarity range has also been proposed by the growing interest for environmental preservation and human health protection..$^{25}$ Our group have been interested in these materials because they can tailored to selective sorption profile based on hydrophobic and hydrophilic properties, shape and size of pores. ${ }^{26} \mathrm{In}$ view of this, peat is a sedentarily accumulated material consisting of dead organic matter in the waterlogged environment. Due to their high content of humic substances, natural peat exhibits favorable physicochemical properties enabling the application in various technical areas, for instance wastewater treatment, pollution monitoring, fuel production, soil fertilizing, and veterinary and human medicine..$^{27}$ Peat, as an adsorbent, is a porous material with highly polar character because it carries polar functional groups such as alcohols, aldehydes, carboxylic acids, ketones and phenolic hydroxides, which can adsorb large quantities of metals, dyes and other organic molecules, whose adsorption capacity is comparable to conventional extracting phase like activated carbon, silica or alumina. ${ }^{28-30}$

Therefore, in the present study, the aim was evaluating the performance of natural peat as an alternative adsorbent material for matrix solid-phase dispersion for the multiclass analysis of the pesticides acephate (organophosphate), chlorpropham (carbamate), pirimicarb (carbamate), bifenthrin (pyrethroid), tetradifon (sulfone) and phosalone (organophosphate) in medicinal plant Cordia salicifolia Cham, which is commercialized in Brazil as diuretic, appetite suppressant and weight loss products, using gas chromatography-mass spectrometry.

\section{Experimental}

\section{Chemicals and reagents}

HPLC grade solvents, dichloromethane, ethyl acetate, cyclohexane, and chloroform, were purchased from Mallinckrodt Baker (Paris, KY, USA). Certified standards of acephate, chlorpropham, pirimicarb, bifenthrin, tetradifon and phosalone were purchased from Dr. Ehrenstorfer (Augsburg, Germany). All standards were at least $97.0 \%$ pure. Analytical grade anhydrous sodium sulfate was supplied from Mallinckrodt Baker. $\mathrm{C}_{18}$-bonded silica $(50 \mu \mathrm{m})$ was obtained from Phenomenex (Torrance, CA, USA) and neutral alumina (70-290 mesh, activity I) from Macherey-Nagel (Düren, Germany).

\section{Pesticide standard solutions}

Stock $500 \mu \mathrm{g} \mathrm{mL}^{-1}$ standard solutions of pesticides were prepared by exact weight and further dissolution of the corresponding compounds in dichloromethane and stored at $-18^{\circ} \mathrm{C}$. These standard solutions were stable for a period of at least 2 months. The working standard solutions were prepared by diluting the stock solutions in dichloromethane as required. Matrix-matched standards were prepared at the same concentrations as those of calibration solutions by adding appropriate amounts of standards to the control matrix extract.

\section{Peat and dry ash material preparation}

Raw peat samples were collected from peatland located in the municipality of Santo Amaro das Brotas, State of Sergipe, Brazil. The samples were air-dried at room temperature as recommended in the literature, sieved through a 48-mesh grid, and then stored in jars at room temperature. ${ }^{30}$ The dry ash was obtained after ignition of peat at $750{ }^{\circ} \mathrm{C}$ for $4 \mathrm{~h} .{ }^{31}$

\section{Porangaba sample preparation and fortification}

Dried porangaba leaves (Cordia salicifolia Cham; family Boraginaceae) samples used for method development were purchased in the bulk packages format from a local market 
located in the municipality of Aracaju, State of Sergipe, Brazil. No indication as regards the geographical origin of the plant samples was given in the labels. A representative portion of medicinal plant $(100 \mathrm{~g})$ was homogenized using a household blender, sieved (1-2 mm), and stored in jars away from light and moisture until used for analysis. Fortified samples were prepared by adding $500 \mu \mathrm{L}$ of a mixture of the standard solutions to $0.5 \mathrm{~g}$ of sample resulting in two final concentrations 0.5 and $1.0 \mathrm{mg} \mathrm{kg}^{-1}$ of pesticides in the sample. The fortified plant samples were left to stand for $30 \mathrm{~min}$ at room temperature to allow the solvent to evaporate before extraction. Seven (neutral alumina) or three (peat) replicates were analyzed at each fortification level. The extraction procedure is described below.

\section{Extraction procedure}

An aliquot of dried and powdered medicinal plant $(0.5 \mathrm{~g})$ was placed into a glass mortar $(\mathrm{ca} .50 \mathrm{~mL})$ and $0.5 \mathrm{~g}$ of sorbent material (neutral alumina or peat material) was added. The medicinal plant was then gently blended into the sorbent material with a glass pestle, until a homogeneous mixture was obtained ( $c a .1 \mathrm{~min}$ ). The homogenized mixture was introduced into a $100 \times 20 \mathrm{~mm}$ i.d. polypropylene column, filled with $0.1 \mathrm{~g}$ of silanized glass wool at the base, followed by, in order, $1.0 \mathrm{~g}$ of anhydrous $\mathrm{Na}_{2} \mathrm{SO}_{4}$ and $0.5 \mathrm{~g}$ of $\mathrm{C}_{18}$. A $30 \mathrm{~mL}$ portion of cyclohexane:dichloromethane $(3: 1, \mathrm{v} / \mathrm{v})$ was added to the column and the sample was allowed to elute dropwise. Columns were placed on an 18-port vacuum manifold. The eluent was collected into a graduated conical tube and concentrated to a volume of $1 \mathrm{~mL}$, using first a rotary vacuum evaporator $\left(40^{\circ} \mathrm{C}\right)$, followed by a gentle flow of nitrogen. A $1 \mu \mathrm{L}$ portion of the extract was then directly analyzed by GC/MS.

\section{Characterization of peat material}

A Carlo Erber 1110 elemental analyzer was used to determine the elemental compositions of the peat samples. Detailed mineralogical studies of peat samples were carried out using X-ray diffraction (Siemens D-5000), with step time $1 \mathrm{~s}$, step size $0.05 \mathrm{dg}$ and wavelength $1.54 \AA$. The experimental XRD patterns have been indexed using the international JCPDF (Joint Committee for Powder Diffraction Files) database, searchable by the position of the X-ray diffraction peaks.

\section{GC/MS system and operating conditions}

A Shimadzu system (Kyoto, Japan), consisting of a QP-5050A mass spectrometer equipped with a GC-17A gas chromatograph with a Shimadzu AOC 20i auto-injector and a split/splitless injector, was used for the identification and quantification of the pesticides studied. A fused-silica column DB-5MS (5\% phenyl + 95\% polydimethylsiloxane; $30 \mathrm{~m} \times 0.25 \mathrm{~mm}$ id, $0.25 \mu \mathrm{m})$, supplied by J\&W Scientific (Folsom, CA, USA), was employed, with helium $(99.999 \%$ purity) as carrier gas at a flow-rate of $1.4 \mathrm{~mL} \mathrm{~min}^{-1}$. The column temperature was programmed as follows: $60^{\circ} \mathrm{C}$ for $1 \mathrm{~min}$, then directly to $300{ }^{\circ} \mathrm{C}$ at $10{ }^{\circ} \mathrm{C} \mathrm{min}-1$ and holding for $3 \mathrm{~min}$. The solvent delay was $5 \mathrm{~min}$. The injector port was maintained at $250^{\circ} \mathrm{C}$, and $1 \mu \mathrm{L}$ sample volumes were injected in splitless mode $(0.7 \mathrm{~min})$. The data were acquired and processed with a personal computer with Shimadzu class 5000 software. The total analysis time was $28 \mathrm{~min}$ and equilibration time 2 min.

The eluent from the GC column was transferred via a transfer line heated at $280^{\circ} \mathrm{C}$, and fed into a $70 \mathrm{eV}$ electron impact ionization source, also maintained at $280{ }^{\circ} \mathrm{C}$. The analysis was performed in the selected ion monitoring (SIM) mode. For the first acquisition window (5.0 to $10.0 \mathrm{~min})$, the ions monitored were $\mathrm{m} / \mathrm{z}, 136,142$ and 168 (acephate). For the second acquisition window (11.0 to $20.0 \mathrm{~min}$ ), the ions monitored were $\mathrm{m} / \mathrm{z} \mathbf{1 5 4}, 171$ and 213 (chlorpropham), $\mathrm{m} / \mathrm{z}, 152,166$ and 238 (pirimicarb). For the third acquisition window (20.0 to $28.0 \mathrm{~min}$ ), the ions monitored were $\mathrm{m} / \mathrm{z}, 165, \mathbf{1 8 1}$, and 322 (bifenthrin), $\mathrm{m} / \mathrm{z}, 227,356$ and 362 (tetradifon), $\mathrm{m} / \mathrm{z}, 121,257$ and 367 (phosalone). Values of $\mathrm{m} / \mathrm{z}$ in bold type correspond to the quantification ion for each analyte.

\section{Results and Discussion}

\section{Characterization of peat and dry ash material}

The elemental analyses of the tropical peat from Santo Amaro das Brotas showed the values C (53.1\%), H (6.0\%), $\mathrm{O}(31.5 \%)$ and dry ash $(9.4 \%)$. Typical compositions of peat are in the range $40-60 \% \mathrm{C}$ and $4-6 \% \mathrm{H}^{29}$ The elemental ratios $\mathrm{H} / \mathrm{C}(1.3)$ and $\mathrm{O} / \mathrm{C}(0.4)$ are indicators for the percentage saturation of the $\mathrm{C}$ atoms within the organic molecule and of the carbohydrate content respectively. Lower $\mathrm{H} / \mathrm{C}$ ratios indicate higher aromaticity in the samples. The lowest $\mathrm{O} / \mathrm{C}$ ratio of the peat sample indicates the lowest carbohydrate level and/or the highest organic content of that peat sample. The estimate value of the organic matter was $96 \%$ for the peat sample. ${ }^{36}$

Detailed examination of the mineralogy of peat sample using XRD is shown in the Figure 1. The XRD of peat sample (Figure 1a) is characteristic of amorphous matter with a hump, between $18^{\circ}$ and $32^{\circ}$. Bozkurt et al. ${ }^{30}$ analyzing the processes involved in peat formation, 
recognized an anaerobic thick structural layer, which is formed of residual material from the original plant structure, decay products and new substances produced mainly by bacteria. At this level peat would be amorphous and highly humified. However, only the XRD of dry ash or residue of that sample revealed mineral characteristics with presence of quartz mineral and some clay material. These materials were covered by the organic matter of peat (Figure 1b). The combination of the elemental analyses and XRD indicate that the peat studied is highly humified and rich in organic compounds.
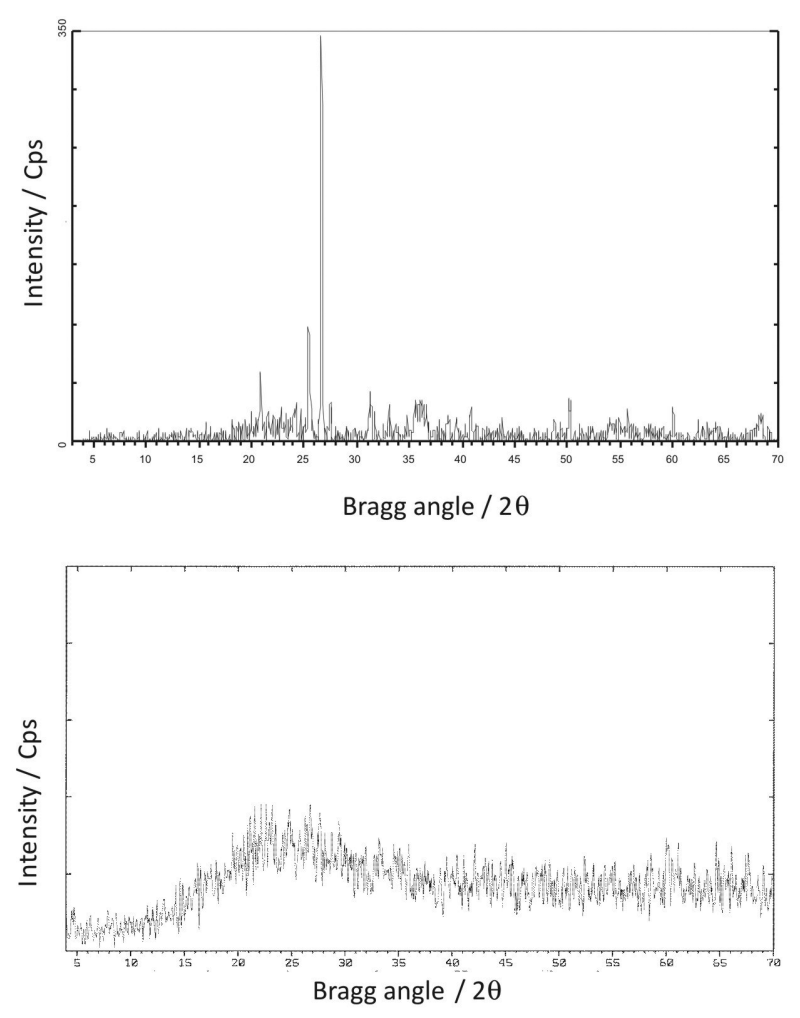

Figure 1. X-ray diffractometer of peat in natura (a) and dry ash sample (b).

\section{MSPD procedure}

In this study, the performance of the peat material as sorbent for matrix solid-phase dispersion was evaluated and compared with neutral alumina, which was used as extracting phase to carry out the multiclass analysis of the pesticides (acephate, chlorpropham, pirimicarb, bifenthrin, tetradifon and phosalone) in medicinal plant Cordia salicifolia in our previous developed and validated MSPD procedure. ${ }^{25}$ On the other hand, considering that there are no Brazilian regulations concerning maximum permissible pesticide residue concentrations in medicinal herbs, recovery experiments were carried out, in seven replicates, at two arbitrary fortification levels $\left(0.5\right.$ and $\left.1.0 \mathrm{mg} \mathrm{kg}^{-1}\right)$ to the medicinal plant matrix. The recoveries from fortification studies of the six pesticides were evaluated by GC/MS (SIM) based on external calibration using medicinal herbmatched standards. Average recoveries ranged from $i$ ) 62.9 to $129.9 \%$, with relative standard deviations (RSD) values of 6.3 to $26 \%$ using neutral alumina as sorbent, ii) 64 to $118 \%$, with RSD values of 5.6 to $26.4 \%$, using peat material as sorbent and iii) 1.3 to $19.2 \%$, with RSD values of 5.0 to $14.8 \%$, using dry ash or residue of the peat as sorbent; here for chlorpropham, bifenthrin and phosalone, there were not recovery (Table 1). Concentrations were calculated by comparing peak areas from extracted ion current profiles with those obtained from matrix-matched standards. Table 1 presents recoveries of the six pesticides at two concentration levels for the medicinal herb. Considering the acceptability criteria for recovery in the range of $70-130 \%$, acephate, chlorpropham, pirimicarb, bifenthrin, tetradifon, and phosalone presented good to excellent recoveries from medicinal herb sample. Comparison of peat material as sorbent with the commercially available neutral alumina showed peat material as a similar extracting phase for the six pesticides under investigation. Results of the peat dry ash or mineral residue when used as sorbent were lowest, unsatisfactory, identifying the organic fraction as the responsible by sorption of the six pesticides. A recent study employing the same peat had been concluded that overall adsorption to $\mathrm{Cr}^{\mathrm{III}}$ could be explained by the efficiency of adsorption of the elevated organic matter content of the peat, that is related with physicochemical properties and the presence of polar functional groups on the surface. ${ }^{32}$

The linearity of a method is a measure of range within which detector response is directly proportional to the concentration of analyte in standard solutions or samples. Linearity for all compounds were determined using blank medicinal herb samples fortified at eight concentration levels $\left(0.10,0.20,0.40,0.50,1.0,2.0,4.0\right.$ and $\left.5.0 \mathrm{mg} \mathrm{kg}^{-1}\right)$. At each analyte amount, two replicate measurements were made. The slope and intercept values, together with their standard deviations, were determined using regression analyses. Linear regression coefficients for all pesticides ranged from 0.9975 to 0.9986 . These results indicated the correct linearity of the calibration curves at the respective spiking levels. The limits of detection (LOD) for the pesticides studied were calculated considering the standard deviation of the analytical noise (a value of seven times the standard deviation of the blank) and the slope of the regression line, and ranged from 0.10 to $0.15 \mathrm{mg} \mathrm{kg}^{-1}$. The limits of quantification (LOQ) were determined as the lowest concentration giving a response of ten times the average of the baseline noise, calculated using seven unfortified samples. The LOQ values for these compounds 
Table 1. Average \% recoveries (RSD\%) of fortified pesticides in medicinal plant from MSPD method with GC/MS analysis

\begin{tabular}{|c|c|c|c|c|c|c|c|}
\hline \multirow{3}{*}{ Pesticide } & \multirow{3}{*}{$\begin{array}{c}\text { Fortification } \\
\text { level } \\
\left(\mu \mathrm{g} \mathrm{g}^{-1}\right)\end{array}$} & $\begin{array}{c}\text { Mean recovery* } \\
(\%)\end{array}$ & $\begin{array}{l}\mathrm{RSD} \\
(\%)\end{array}$ & $\begin{array}{c}\text { Mean recovery* } \\
(\%)\end{array}$ & $\begin{array}{l}\text { RSD } \\
(\%)\end{array}$ & $\begin{array}{c}\text { Mean recovery\# } \\
(\%)\end{array}$ & $\begin{array}{l}\text { RSD } \\
(\%)\end{array}$ \\
\hline & & \multicolumn{6}{|c|}{ sorbent/co-sorbent } \\
\hline & & \multicolumn{2}{|c|}{ alumina/ $\mathrm{C}_{18}$} & \multicolumn{2}{|c|}{ peat $/ \mathrm{C}_{18}$} & \multicolumn{2}{|c|}{ dry ash/C 18} \\
\hline \multirow{2}{*}{ acephate } & 0.5 & 85.7 & 19.7 & 65.0 & 20.3 & 2.5 & 10.8 \\
\hline & 1.0 & 62.9 & 15.8 & 64.0 & 9.0 & 3.2 & 8.0 \\
\hline \multirow{2}{*}{ chlorpropham } & 0.5 & 115.8 & 10.6 & 117.0 & 9.1 & ND & - \\
\hline & 1.0 & 129.9 & 11.3 & 100.0 & 20.1 & ND & - \\
\hline \multirow{2}{*}{ pirimicarb } & 0.5 & 117.6 & 12.4 & 106.0 & 5.6 & 19.2 & 5.0 \\
\hline & 1.0 & 81.3 & 7.7 & 91.0 & 10.8 & 16.1 & 14.8 \\
\hline \multirow{2}{*}{ bifenthrin } & 0.5 & 94.6 & 26.0 & 113.0 & 23.1 & ND & - \\
\hline & 1.0 & 84.1 & 6.3 & 94.0 & 5.7 & ND & - \\
\hline \multirow{2}{*}{ tetradifon } & 0.5 & 108.5 & 24.1 & 88.0 & 26.4 & 2.1 & 6.2 \\
\hline & 1.0 & 82.5 & 11.0 & 91.0 & 19.1 & 1.3 & 9.1 \\
\hline \multirow{2}{*}{ phosalone } & 0.5 & 105.1 & 19.7 & 118.0 & 20.9 & ND & - \\
\hline & 1.0 & 78.5 & 15.9 & 113.0 & 10.6 & ND & - \\
\hline
\end{tabular}

$*_{\mathrm{n}}=7 ;{ }^{\mathrm{n}}=3 ; \mathrm{ND}=$ no detected.

ranged from 0.15 to $0.25 \mathrm{mg} \mathrm{kg}^{-1} \cdot{ }^{33-35}$ The repeatability of the chromatographic method was performed by successive six time analyses of $5.0 \mu \mathrm{g} \mathrm{mL^{-1 }}$ of pesticide standard solution, and presented as the relative standard deviations, which was in the range of $1.8-3.2 \%$.

Finally, considering that one of the aims of our work has been to explore the scientific and technological feasibility of alternative materials as versatile sorbents for solid-phase extraction of pesticide residues from medicinal plants, with minimum sample preparation and time consumption, economical aspects have not been in the foreground, but they are clearly a consequence. Therefore, the low operating cost of the peat when compared with other commercial sorbents as alumina is enormous. The cost of peat is $c a$. US\$ $0.09 \mathrm{~kg}^{-1}$, much lower than commercial alumina $c a$. US\$ $110.00 \mathrm{~kg}^{-1} \cdot{ }^{29}$

\section{Application of the method to real samples}

The MSPD procedure developed was applied to the determination of pesticides in medicinal plant Cordia salicifolia. Four different samples of this medicinal plant, obtained from local markets in the city of Aracaju (Brazil) originated from conventional agriculture, were analyzed using this procedure. No pesticide residues, at concentrations above the limit of detection, were found in these samples.

\section{Conclusions}

An alternative extracting phase for matrix solid-phase dispersion was characterized and tested in the multiclass analysis of pesticides in medicinal herb. Results have shown that the peat material can be successfully applied for analysis of acephate, chlorpropham, pirimicarb, bifenthrin, tetradifon and phosalone in medicinal herb Cordia salicifolia. This solid-phase method may be useful as a screening protocol to identify pesticides in medicinal herb by industrial pharmaceutical and official regulatory laboratories since peat is an abundant natural material and cheaper than commercial sorbents.

\section{Acknowledgments}

The authors wish to thank MCT/CNPq (process No. 620247/2008-8) for the financial support of this study and researchship. P.H.V.C., A.M.D.J. and D.S.S.B. also thank the CAPES for the fellowships provided.

\section{References}

1. Abhilash, P. C.; Singh, N.; Bull. Environ. Contam. Toxicol. 2008, 81, 604.

2. Rodrigues, M. V. N.; Reyes, G. R. F.; Magalhães, P. M.; Rath, S.; J. Braz. Chem. Soc. 2007, 18, 135.

3. Menghini, L.; Epifano, F.; Leporini, L.; Pagotti, R.; Tirillini, B.; J. Med. Food 2008, 1, 193.

4. Schreck, E.; Geret, F.; Gontier, L.; Treilhou, M.; Talanta 2008, 77, 298.

5. European Pharmacopoeia, Conseil de l'Europe: Strasbourg, 1997.

6. Zuin, V. G.; Yarewake, J. H.; Lanças, F. M.; J. Braz. Chem. Soc. 2003, 14, 304.

7. Poole, C. F.; J. Chromatogr., A 2007, 1158, 241. 
8. Santos, T. F. S.; Aquino, A.; Dórea, H. S.; Navickiene, S.; Anal. Bioanal. Chem. 2008, 390, 1425.

9. Silva, M. G. D.; Aquino, A.; Dórea, H. S.; Navickiene, S.; Talanta 2008, 76, 680.

10. García de Llasera, M. P.; Reyes-Reyes, M. L.; Food Chem. 2009, 114, 1510.

11. Frenich, A. G.; Bolamos, P. P.; Vidal, J. L. M.; J. Chromatogr., A 2007, 1153, 194.

12. Hercegová, A.; Dömötörová, M.; Kruzlicová, D.; Matisová, E.; J. Sep. Sci. 2006, 29, 1102.

13. Abhisash, P. C.; Jamil, S.; Singh, N.; J. Chromatogr., A, 2007, 1176, 43.

14. Barker, S. A.; J. Chromatogr., A 2000, 885, 115.

15. Barker, S. A.; J. Chromatogr., A 2000, 880, 63.

16. Barker, S. A.; Biochem. Biophys. Methods 2007, 70, 151.

17. Tang, F.; Yue, Y.; Hua, R.; Cão, H.; J. AOAC Int. 2006, 89, 489.

18. Tang, F.; Yue, Y.; Hua, R.; Ge, S.; Tang, J.; J. AOAC Int. 2005, 88,720 .

19. Liang, Y. Z.; Xie, P.; Chang, K.; J. Chromatogr., B: Anal. Technol. Biomed. Life Sci. 2004, 812, 53.

20. Lino, C. M.; Guarda, L. M. C.; Silveira, M. I. N.; J. AOAC Int. 1999, 82, 1206.

21. Zuin, V. G.; Vilegas, J. H. Y.; Phytother. Res. 2000, 14, 73.

22. Wu, J.; Li, L.; Zou, Y.; J. AOAC Int. 2005, 88, 1261.

23. Jeong, M. L.; Zahn, M.; Trinh, T.; Brooke, F. A.; Ma, W. W.; J. AOAC Int. 2008, 91, 630.

24. Abad, F. C.; Winck, P. R.; Benvenutti, E. V.; Peralba, M. C. R.; Caramão, E. B.; Zini, C. A.; J. Sep. Sci. 2007, 30, 2109.

25. Carvalho, P. H. V.; Prata, V. M.; Alves, P. B.; Navickiene, S.; J. AOAC Int. 2009, 92, 1184.
26. Carvalho, P. H. V.; Barreto, A. S.; Rodrigues, M. O.; Mesquita, M. E.; Alves Júnior, S.; Prata, V. M.; Alves, P. B.; Navickiene, S.; J. Sep. Sci. 2009, 32, 2132.

27. Romão, L. P. C.; Lead, J. R.; Rocha, J. C.; Oliveira, L. C.; Rosa, A. H.; Mendonça, A. G. R.; Ribeiro, A. S.; J. Braz. Chem. Soc. 2007, 18, 714.

28. Brown, P. A.; Gill, S. A.; Allen, S. J.; Water Res. 2000, 34, 3907. 29. Mohan, D.; Pittman Jr, C. U.; J. Hazard Mater. 2006, 137, 762.

30. Fernandes, A. N.; Almeida, C. A. P.; Menezes, C. T. B.; Debacher, N. A.; Sierra, M. M. D.; J. Hazard Mater. 2007, 144, 412.

31. Bozkurt, S.; Lucisano, M.; Moreno, L.; Neretnieks, I.; EarthSci. Rev. 2001, 53, 95.

32. Batista, A. P. S.; Romão, L. P. C.; Arguelho, M. L. P. M.; Garcia, C. A. B.; Alves, J. P.; Passos, E. A.; Rosa, A. H.; J. Hazard Mater. 2009, 163, 517.

33. Bliesner, D. M.; Validating Chromatographic Methods - A Practical Guide; John Wiley \& Sons Publications: New Jersey, 2006.

34. SANCO No. 10232/2006; Quality Control Procedures for Pesticide Residues Analysis; The European Commission: United Kingdom, 2006.

35. Tadeo, J. L.; Analysis of Pesticides in Food and Environmental Samples, CRC Press: New York, 2008.

36. Rodella, A. A.; Alcarde, J. C.; Sci. Agric. (Piracicaba, Braz.) 1994, 51, 556 (http://www.scielo.br/pdf/sa/v51n3/29.pdf).

Received: July 28, 2009

Web Release Date: December 16, 2009 